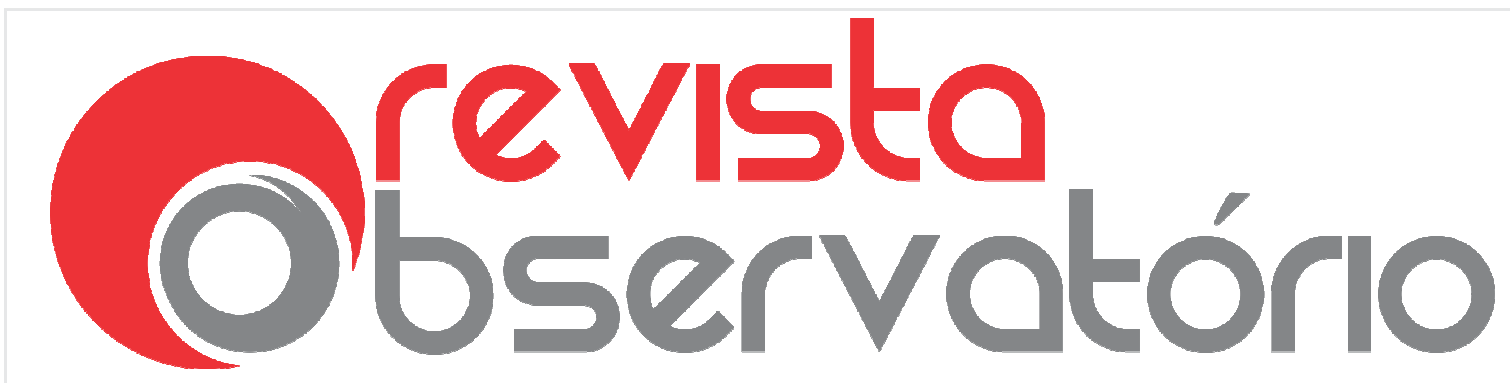

\title{
DEMOCRACIA FEMINISTA CONTRA O FASCISMO: \\ Entrevista com a filósofa Marcia Tiburi
}

\section{Entrevista}

Interview

\section{Entrevista}

\section{Sandra de Souza Machado ${ }^{1,2}$}

Entrevista com Marcia Tiburi, gaúcha, graduada em Filosofia e Artes. É mestre e doutora em Filosofia (UFRGS, 1999). Publicou diversos livros de Filosofia, entre eles: "As Mulheres e a Filosofia" (Ed. Unisinos, 2002); "Filosofia Cinza - a melancolia e o corpo nas dobras da escrita" (Escritos, 2004); "Mulheres, Filosofia ou Coisas do Gênero" (EDUNISC, 2008), "Filosofia em Comum" (Ed. Record, 2008), "Filosofia Brincante" (Record, 2010), "Olho de Vidro" (Record, 2011), "Filosofia Pop" (Bregantini, 2011); "Sociedade Fissurada" (Record, 2013); "Filosofia Prática, ética, vida cotidiana, vida virtual" (Record, 2014); "Como conversar com um fascista - Reflexões sobre o cotidiano autoritário brasileiro" (Record, 2015). Publicou também os romances "Magnólia" (2005), "A Mulher de Costas" (2006), "O Manto" (2009), "Era meu esse Rosto" (Record, 2012), e "Uma

\footnotetext{
${ }^{1}$ Doutora em História pela Universidade de Brasília (UnB) e Master of Arts em Cinema e TV pela The American University, Washington, D.C. EUA. É professora visitante da UnB, jornalista e blogueira. E-mail: sandramachado14@gmail.com.

2 Endereço de contato do autor (por correio): Universidade de Brasília, Faculdade de Comunicação. Campus Universitário Darcy Ribeiro, Instituto Central de Ciências Norte, prédio Minhocão Asa Norte, CEP: 70910-900, Brasilia (DF), Brasil.
} 


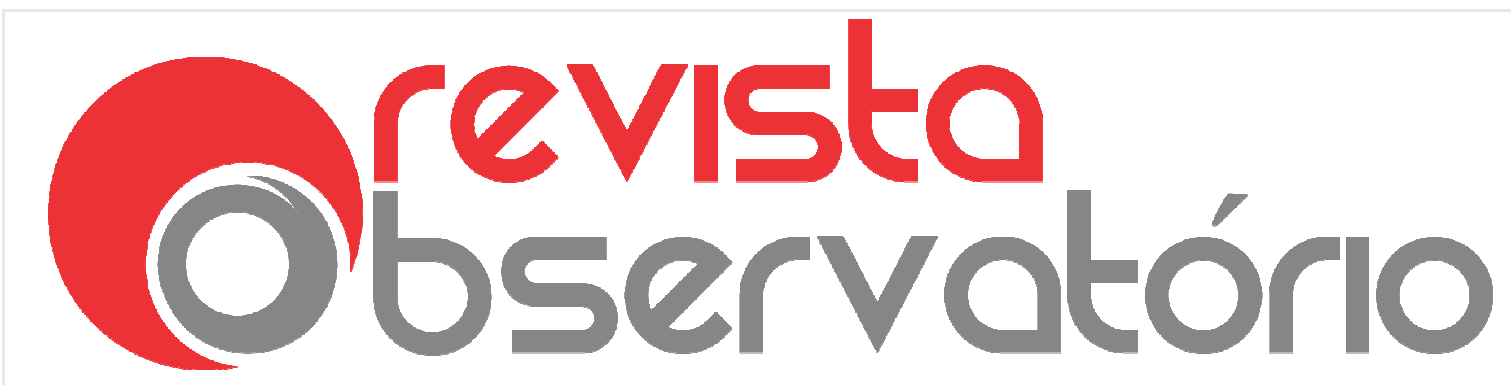

ISSN n² 2447-4266

Vol. 3, n. 1, Janeiro-Março. 2017

DOI: http://dx.doi.org/10.20873/uft.2447-4266.2017v3n1p480

fuga perfeita é sem volta" (Record, 2016). É autora ainda dos livros Diálogo/desenho (2010), Diálogo/dança (2011), Diálogo/Fotografia (2011) e Diálogo/Cinema (2013) e Diálogo/Educação (2014), todos publicados pela editora SENAC-SP. É também blogueira e colunista da revista Cult.

Recebido em: 22.03.2017. Aceito em: 25.03.2017. Publicado em: 30.03.2017. 


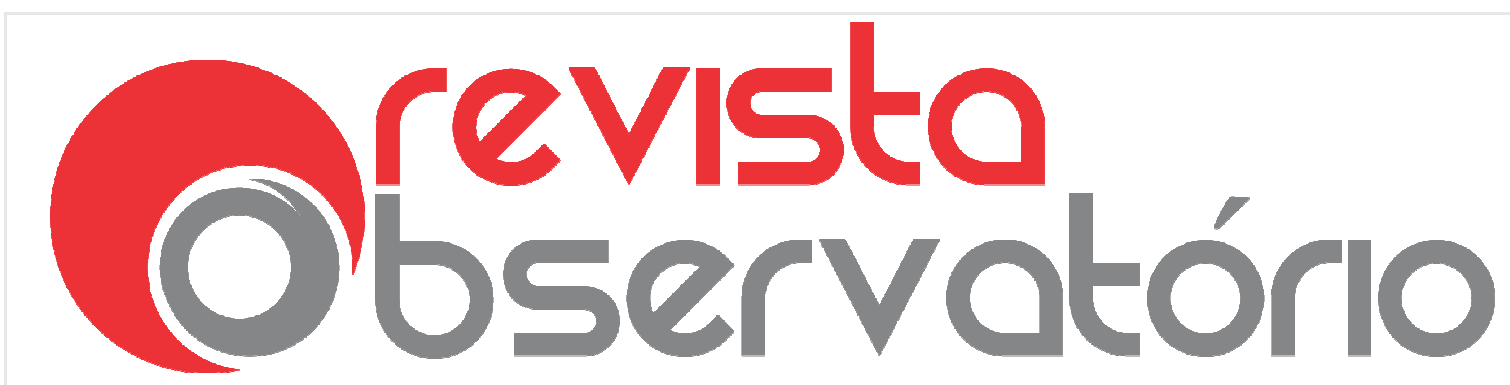

ISSN n² 2447-4266

Vol. 3, n. 1, Janeiro-Março. 2017

DOI: http://dx.doi.org/10.20873/uft.2447-4266.2017v3n1p480

A filósofa Marcia Tiburi - escritora bem-sucedida de vários livros de ficção e não-ficção, professora universitária, e reconhecida ativista pelos direitos das mulheres -acredita que é preciso contextualizar as ações e políticas para e pelas mulheres. "A esfera política está minada. Há o autoritarismo brasileiro, na política e também no cotidiano", afirma. Ela é idealizadora e uma das fundadoras do movimento político PartidA, que ainda está em formação, mas já se espalha por todo o Brasil. Nascida em maio de 2015, a PartidA tomou corpo nas redes sociais e arrebanha militantes - mulheres que atuam em todas as áreas e pertencem às diversas classes sociais, etnias, idades e orientações sexuais - tanto no mundo digital como em reuniões presenciais nas principais cidades e capitais.

Nos preceitos da PartidA, há a necessidade de políticas praticadas e idealizadas de forma horizontal, a partir das comunidades, até para se eleger futuras representantes, como deputadas federais e estaduais, senadoras, vereadoras e prefeitas. "Isso com a ideia de que nós vamos fomentar uma democracia feminista!", arremata Marcia. Ela conta que pensou em reunir-se às outras mulheres feministas que conhece para pensar conjuntamente, por necessidade. "Sentia-me muito só em meu feminismo"!

Márcia é gaucha da pequena cidade de Vacaria (nordeste do RS), casada, e mãe de uma jovem de 20 anos. Estudou em Porto Alegre, onde cursou Filosofia e Artes; residiu em São Paulo e lecionou no Programa de PósGraduação em Educação, Artes e História da Cultura, da Universidade 


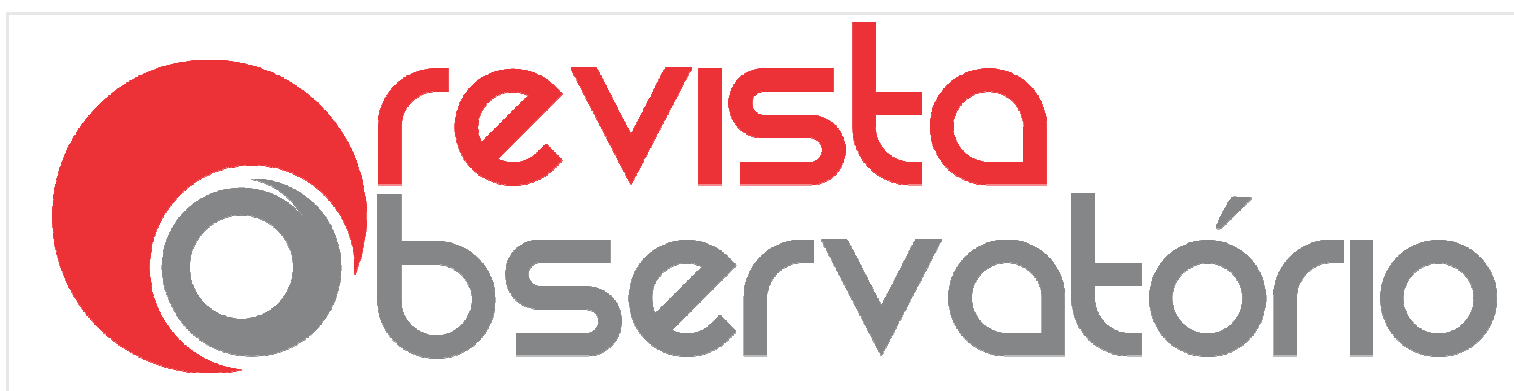

ISSN n² 2447-4266

Vol. 3, n. 1, Janeiro-Março. 2017

DOI: http://dx.doi.org/10.20873/uft.2447-4266.2017v3n1p480

Mackenzie. Atualmente, mora no Rio de Janeiro. "Adoraria ficar só escrevendo meus romances, livros, mas não é possível fazer poesia no Brasil, atualmente, quando tudo nos chama para a política. Eu me sinto convocada! É um efeito do trabalho com a teorização filosófica", reflete ela.

1. Como você analisa, nesta era (pós) moderna e colonial, as representações, e os estereótipos, das mulheres nas mídias audiovisuais, impressas - em interação com as redes sociais? A crescente onda de radicalização de extremos - direita, esquerda, fascismo, fanatismos, fundamentalismos - provoca backlash de forma generalizada ou há avanços? No longo prazo, o que se pode esperar para os direitos das mulheres no país ou na pequena aldeia global?

MT - As mulheres sempre foram objeto de estereótipos. A "estereotipificação" é uma ação organizada por discursos e práticas que faz parte do projeto misógino historicamente lançado contra as mulheres. Onde há machismo (a versão de gênero do capitalismo), há estereotipificação do "Outro", no caso, da "mulher" e de todos aqueles que não se encaixam no paradigma masculinista, ele mesmo uma máquina de produção de estereótipos. Nesse sentido, a luta feminista tem sua máxima consistência contra a produção dos estereótipos em nome da singularidade de cada mulher, de cada pessoa que faz parte das minorias políticas. A fascistização da sociedade contemporânea leva à intensificação desses processos em que o outro não conta como alteridade, mas apenas como objeto. Creio que essa grande tensão precisa ser analisada. Talvez, a luta hoje não seja entre esquerda e direita, mas entre feminismo e fascismo. O feminismo se apresenta, a meu ver, como a grande luta, o caminho 


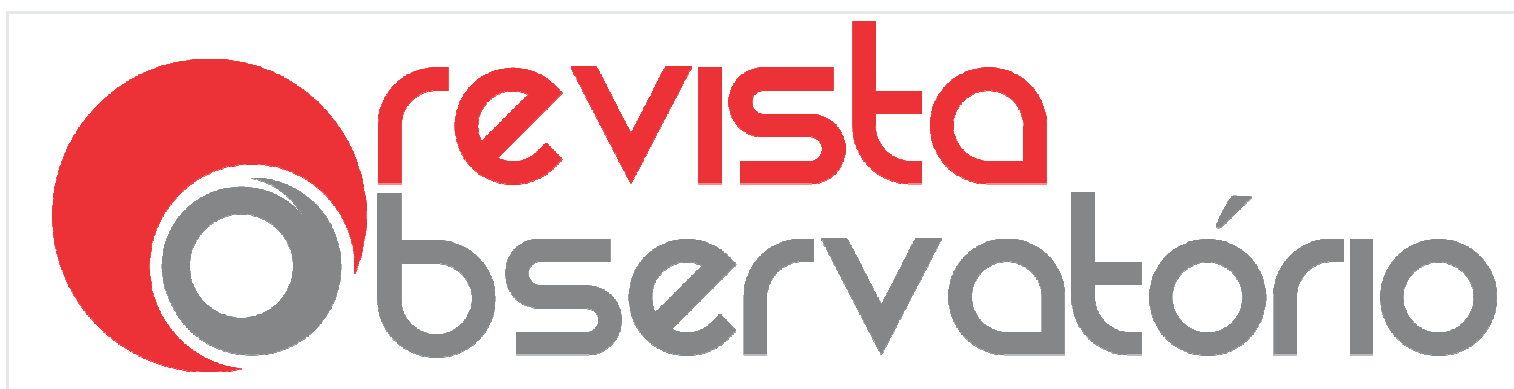

ISSN n² 2447-4266

Vol. 3, n. 1, Janeiro-Março. 2017

DOI: http://dx.doi.org/10.20873/uft.2447-4266.2017v3n1p480

que pode levar a recuperar direitos perdidos e produzir uma sociedade mais igualitária e mais justa.

2. No Brasil, bem como em muitos países do Ocidente, as mulheres lutam batalhas intensas e até conseguem algum espaço na produção, direção e criação audiovisual, seja ficção ou não-ficção. Também travam batalhas na imprensa tradicional ou na esfera digital, sobretudo por melhores salários - ainda bem desiguais -, em feudos antes dominados por homens. Ainda que representem apenas algo entre 10 a $20 \%$ da criação na indústria do entretenimento (que engloba e imprensa), você acredita que faz diferença nas representações quando as produções são de mulheres, pensadas por elas?

MT - Se olharmos para a história do audiovisual, sobretudo do cinema, veremos que as mulheres tiveram uma intensa participação na construção do cinema em todos os países, até o momento em que o cinema se tornou uma grande indústria e os homens tomaram o seu lugar. A aliança entre machismo e capital é antiga e se renova a cada dia. Creio que as mulheres de luta, as feministas, precisam combater o machismo combatendo também o capital. Combater o machismo é, portanto, combater a indústria cultural, ao mesmo tempo que esse combate não se dá sem que tomem para si o poder sobre os meios de produção. Esse é o primeiro passo na transformação anti-machista: as feministas comandando os meios de produção.

3. O caso brasileiro que chama atenção, e que ficará marcado na História do país, são as eleições de 2014, que reelegeram Dilma Rousseff, e a 


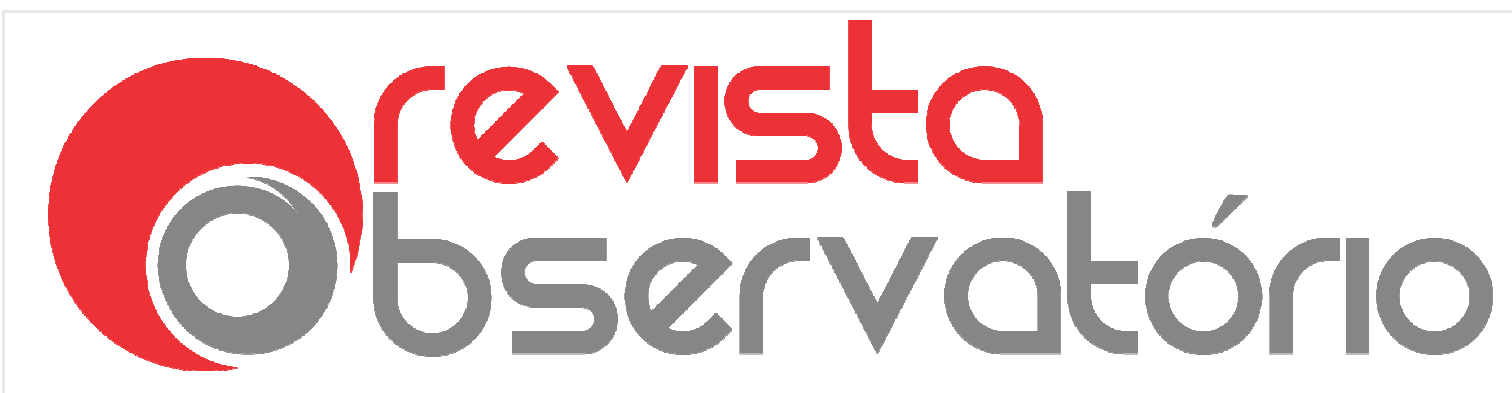

ISSN n² 2447-4266

Vol. 3, n. 1, Janeiro-Março. 2017

DOI: http://dx.doi.org/10.20873/uft.2447-4266.2017v3n1p480

sua deposição, menos de dois anos depois. As batalhas que dividiram - país chocaram as mulheres feministas pelo conteúdo - tanto na mídia mainstream como nas redes sociais - exacerbadamente machista, misógino, LGBTfóbico, classista e racista. Tem sido uma intersecção de valores culturais e sociais arcaicos, mas que vimos estarem bem vivos na sociedade brasileira. Foi uma das determinantes para o "sucesso do golpe", acreditam intelectuais, dentro e fora do país. Como você analisa esse processo de desconstrução da figura feminina no poder, na esfera pública, como ocorreu com Dilma Rousseff?

MT - Eu escrevi um texto sobre o golpe como máquina misógina. Ao "golpear" Dilma Rousseff, o machismo elevado à Razão de Estado golpeia todas as mulheres e, com elas, a Democracia. São dois coelhos com uma só cajadada, como diz no ditado. As mulheres ficam desestimuladas com a política, como de resto toda a população, e consegue-se garantir a perpetuação do poder na mão de elites brancas, capitalistas e machistas. Podemos acrescentar, ruralistas e rentistas. O neoliberalismo, que é a fase mais bizarra do capitalismo que conhecemos, cresce e se desenvolve destruindo tudo ao redor, da educação à saúde. Todos os direitos fundamentais são aviltados e a violência e o terror funcionam como métodos para a submissão. Os corpos já foram preparados para aceitar esse estado de coisas. Creio que as mulheres que não se politizaram, por interesse ou precariedade na educação e na formação política, continuarão ajudando, consciente ou inconscientemente, a máquina misógina que as manipula. Mas, não as feministas. 


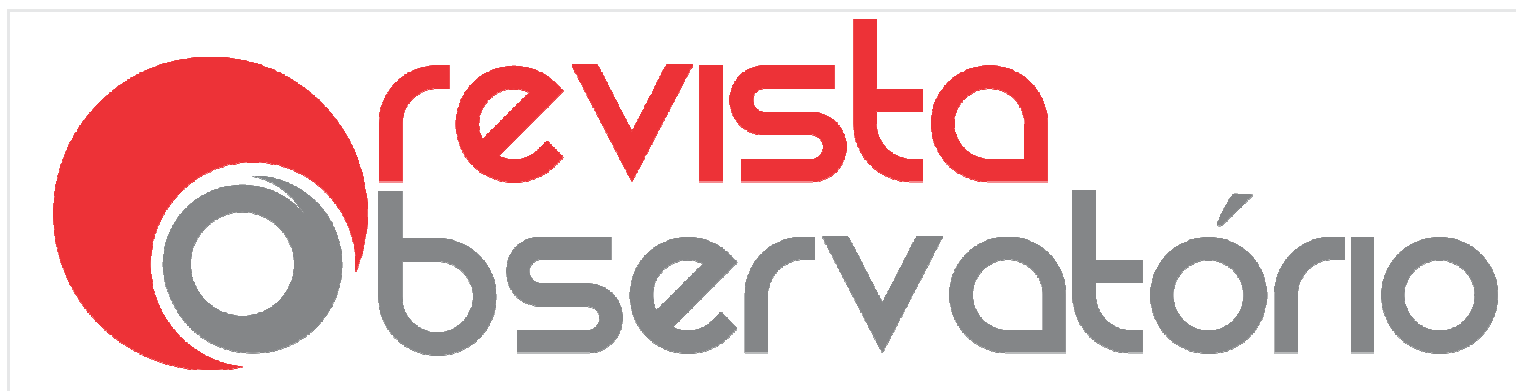

ISSN n² 2447-4266

Vol. 3, n. 1, Janeiro-Março. 2017

DOI: http://dx.doi.org/10.20873/uft.2447-4266.2017v3n1p480

4. O que podemos esperar para o cotidiano, hoje e no futuro, enquanto mulheres brasileiras, que temos que lidar com essa realidade? Os movimentos sociais das mulheres - dentro e fora do mundo digital, das redes sociais - dão resultados? Alertam e mudam algo?

MT - É preciso ocupar o poder. Não vejo outra saída. Ocupar partidos, ruas, espaços públicos em geral. Para 2018, preparamos um número grande de candidaturas de mulheres, na forma de uma ocupação de espaço nos partidos e nas candidaturas. Precisamos começar com bancadas feministas nas assembleias legislativas dos Estados e também no Congresso Nacional. Além de tudo, precisamos fazer isso para causar efeitos na ordem simbólica e, assim, na mentalidade e na ação política concreta.

5. Como vai, nesse sentido, o movimento político (e social) PartidA? Você ajudou a criar, articular e está aí, espalhado pelo país. Elegeu ou elegerá mais mulheres na política brasileira? Hoje, há apenas $10 \%$ delas no Congresso Nacional. O México, por exemplo, é representado por quase $40 \%$ de mulheres no parlamento. A Argentina tem ainda mais. $O$ que acontece aqui?

MT - O projeto do nosso grupo que cresce e se espalha é transformar radicalmente o cenário da representação feminina no parlamento brasileiro. A articulação continua. Os grupos se organizam horizontalmente, a partir de suas próprias potências, com cuidado e dedicação, porque um dos aspectos mais caros a esse movimento é a valorização da singularidade. Ao mesmo tempo, buscamos descobrir um modo de lidar com o poder que não seja autoritário. 


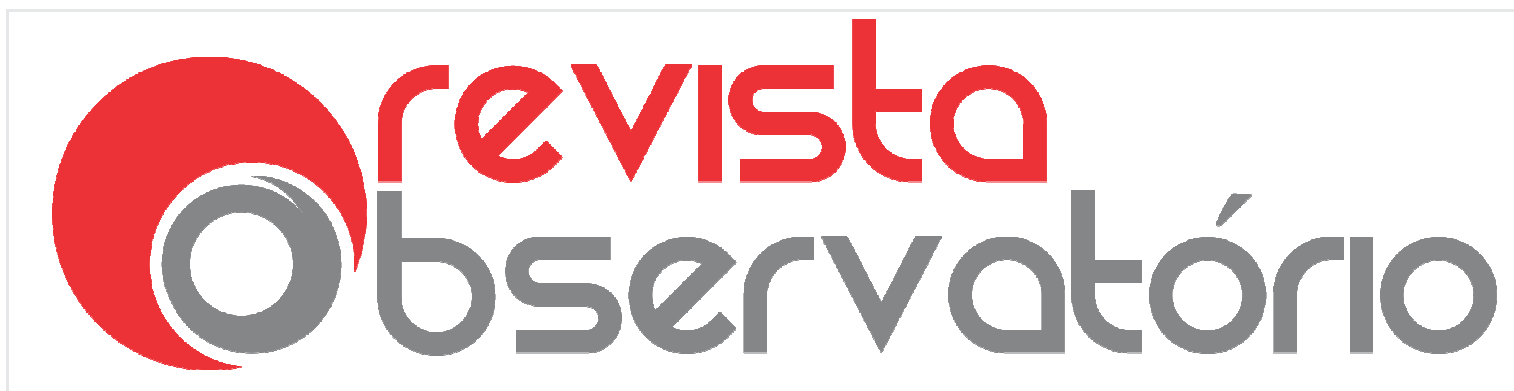

ISSN n² 2447-4266

Vol. 3, n. 1, Janeiro-Março. 2017

DOI: http://dx.doi.org/10.20873/uft.2447-4266.2017v3n1p480

Pensamos que o poder possa ser ação conjunta e não opressão e humilhação. Nesse sentido, os processos de empoderamento e protagonização das outras é o nosso lema.

Em um primeiro momento, experimentamos a movimentação. Isso, o movimento, dá um lastro para a reconstrução da política em um nível cotidiano. Porque isso é algo que nos falta (ao povo brasileiro). Falamos hoje em aniquilação da política, em sua destruição, ou na anti-política. Por quê isso? Porque a esfera da vida política foi minada. Nós nos perdemos porque interrompemos o processo de politização. Isso tem a ver com toda a História do Brasil, sobretudo, a meu ver, com os mais de 20 anos de ditadura militar (entre os anos 1964 e 1985). Foi um período pesadíssimo e um retrocesso muito radical. Foi um atraso, no Brasil, enorme, em termos políticos, culturais, educacionais e éticos. E sofrimentos para todos os lados. Com a abertura (política), a gente começou a engatinhar em direção à democracia. Mas, esta nunca vai se consolidar enquanto projeto de cima pra baixo. A questão que concerne a esse aniquilamento da política e ao autoritarismo em nosso cotidiano diz respeito justamente ao que nós vamos fazer enquanto sociedade civil, enquanto pessoas, umas com as outras, com nosso autoritarismo. O da Ditadura combinava muito com o autoritarismo do brasileiro. De repente, a Ditadura sai de cena em termos governamentais/estatais, mas o autoritarismo não sai da cena cotidiana. Digamos que o autoritarismo ficou um tanto incubado, latente, durante as últimas décadas, mas existe e está de volta à cena política. Agora, desde 2013 (com as grandes manifestações), foi um marco e há um ativismo que se auto-questiona. Há movimentos assim também em escala global, como na Espanha, nos Estados Unidos, na Egito... enfim, isso também no Brasil reflete em volta a uma polarização entre direita e esquerda, algo que 


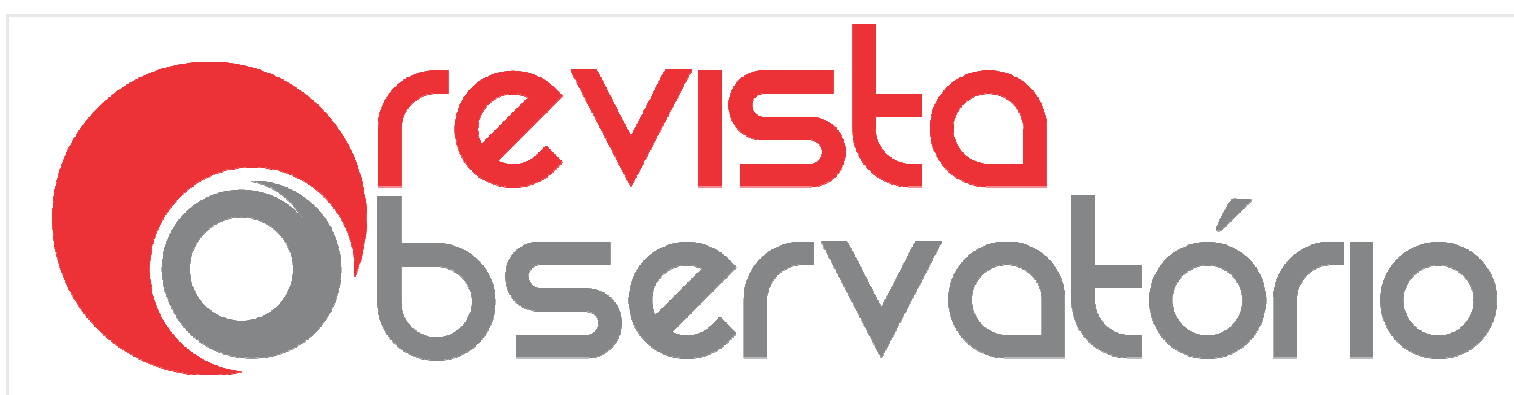

ISSN n² 2447-4266

Vol. 3, n. 1, Janeiro-Março. 2017

DOI: http://dx.doi.org/10.20873/uft.2447-4266.2017v3n1p480

havia sido cancelado, anulado, entre nós. As pessoas se posicionam de novo. Entretanto, direita e esquerda são assuntos reeditados com um certo ranço. $O$ feminismo é uma novidade política!

\section{Bom, isso no Brasil! Feminismo(s) pode ser novidade aqui...}

MT: Então, ao mesmo tempo, em termos de ativismo, ele é mais novidade do que em outros países! É claro, o feminismo é histórico, o feminismo, podemos alegar, tem centenas de anos, milhares... sempre esteve presente, sempre foi uma política que funcionou na margem, subterrânea, como tentativa, como alternativa, e de repente causa um estranhamento justamente que haja a proposição de um partido feminista! Se o feminismo é altamente anárquico, alternativo, não institucional, o quê que um feminismo pode querer com um par-ti-do?! Então, a forma partido causa estranhamento nos contextos dos campos feministas. Ao mesmo tempo, esse estranhamento foi o que produziu a PartidA! Foi nesse contexto que a gente começou a se perguntar, enfim, o quê está nos acontecendo? Então, em termos políticos, o que aconteceu com as feministas? Vamos continuar fazendo essa política alternativa, essa que é da margem, essa que é a mais verdadeira, sincera e real, mas que, ao mesmo tempo, está sempre em um lugar de margem, de subalternidade, posição secundária, que é um lugar ao qual as mulheres se acostumaram! (...) e também que pode ser confortável. Essa questão de um partido feminista provoca o campo feminista. O campo cresce, o feminismo está na moda, as governantes (presidentas) estão na moda. Quer dizer, a nossa presidenta, no caso brasileiro, foi maltratada até as raias do delírio! Mas, é um fato que a evidência, o 


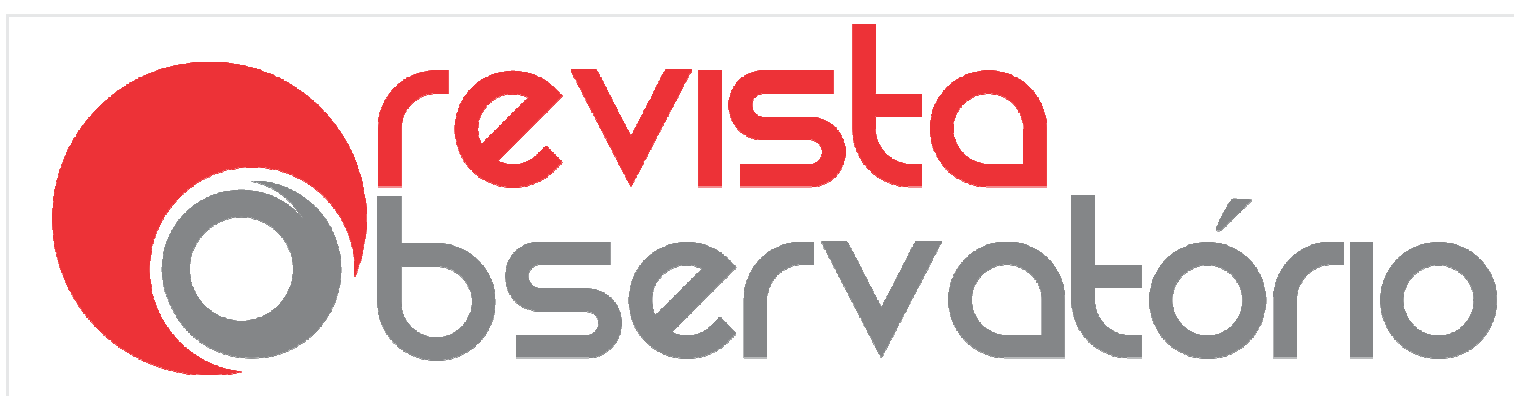

ISSN n² 2447-4266

Vol. 3, n. 1, Janeiro-Março. 2017

DOI: http://dx.doi.org/10.20873/uft.2447-4266.2017v3n1p480

protagonismo das mulheres na política tem crescido. Essa ideia, um tanto incômoda, de um partido feminista é chamativa. Temos que ser críticas e autocríticas em relação a isso, mas isso causa uma comoção. As pessoas se perguntam, se questionam. Há a desconfiança. Isso desde a primeira reunião da PartidA, no Rio de Janeiro, em 2015. E eu disse: gente, isso aqui não é um partido. É uma partidA! Jamais poderia ser igual a um partido político que já existe, dos outros. Então, foi constituído que já éramos um movimento. A PartidA é um diálogo feminista.

\section{E como está sendo organizado esse diálogo na PartidA?}

MT: Rodas de conversas. Horizontalidade. Todas as perspectivas feministas são contempladas, para abarcar todos os feminismos possíveis. Então, a gente quer dialogar com o Outro! Aberto a todo mundo. Isso é ser um partido. No nosso caso, as pessoas não são convidadas a uma filiação mas, sim, a fazer política. E a política é cotidiana. Em uma aula, em uma festa. Em Goiânia, por exemplo, em uma reunião lá, falamos em fazer política municipal. Tem que ser municipal, com as pessoas da cidade. Uma das mulheres disse que tem que ser também nos bairros! Ótimo, então, constrói isso. Façamos também nos bairros. (...) Estou tentando fazer uma filosofia da cultura brasileira. Então, o que está pegando? Qual é o cenário, qual é a música, quais interesses. E eu me dei conta de que somos um país de gente deprimida! Uma cultura de depressão. Aí, vemos todo mundo drogado, tomando Rivotril, Lexotan; crianças tomando Ritalina; outros tomando Prozac... E eu penso que a infelicidade que nos atinge é social e política. Projetos individuais, individualistas, podem ser realizados. Entretanto, eles já não garantem nada! Há a infelicidade política. E eu acho que a PartidA é 


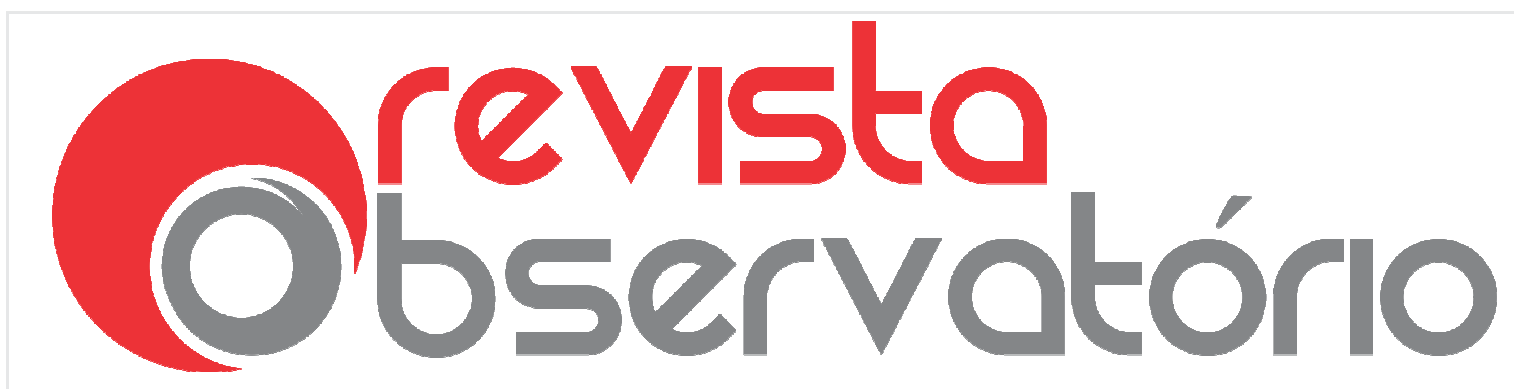

ISSN n² 2447-4266

Vol. 3, n. 1, Janeiro-Março. 2017

DOI: http://dx.doi.org/10.20873/uft.2447-4266.2017v3n1p480

alegria política! Felicidade por ser a promessa de um lugar não-individualista, mas um lugar onde se respeita a singularidade. Onde a singularidade é contemplada, é aceita, é desejada.

\section{Como está a PartidA, virtual e presencial, Brasil afora, com feministas ou as mulheres que não se auto-declaram feministas?}

MT: Muitas feministas chegam até nós com curiosidade e cautela. Há outras pessoas que vêm porque querem fazer política e nunca o fizeram, então a PartidA é este espaço para fazer essa coisa nova. Outras querem um partido pra já. Estamos conversando para decidir rumos, mas é certo que apoiamos e apoiaremos candidatxs nas eleições. Vemos que nas redes sociais, espaços virtuais, e na vida, as pessoas têm muita simpatia pela PartidA. A nossa fanpage do Facebook tem milhares de seguidorxs e as reuniões físicas sempre contam com um número grande de pessoas. A quantidade de gente empolgada com uma iniciativa democrática, no cenário autoritário do Brasil atual, é importante. A ideia é que a organização seja municipal. Em grupos comunitários.

\section{A PartidA é uma causa, um movimento. Pretende ser um partido político organizado? Quais são os objetivos principais?}

MT: Somos, por enquanto, um movimento. Uma mobilização que defende uma democracia feminista. Entendemos que essa democracia se faz com o mais próximo. Que ela é uma construção do comum. $O$ aspecto feminista significa para nós muitas coisas. Uma delas é a construção de uma outra forma de poder 


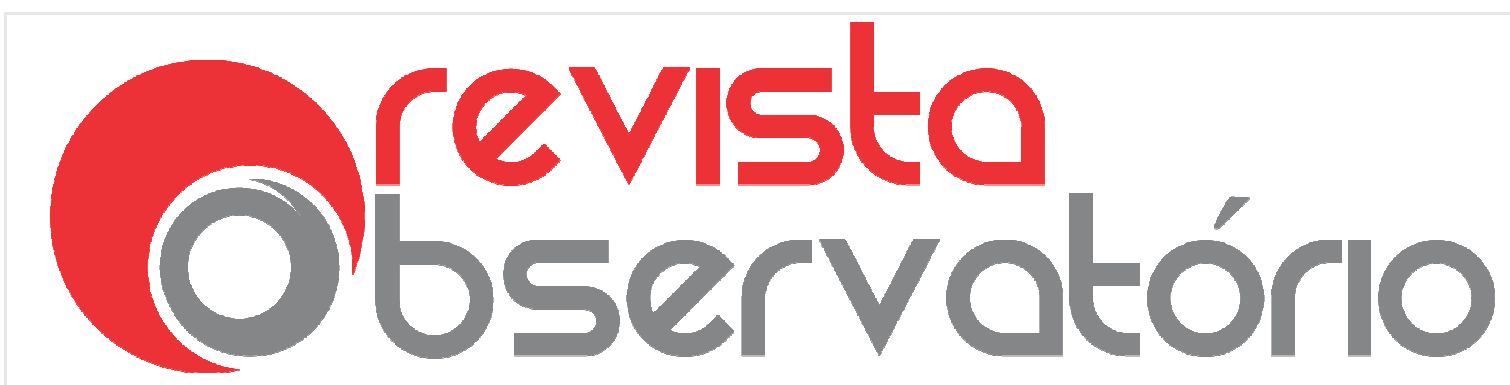

ISSN n² 2447-4266

Vol. 3, n. 1, Janeiro-Março. 2017

DOI: http://dx.doi.org/10.20873/uft.2447-4266.2017v3n1p480

que seja compreensivo, colaborativo, partilhado. Pretendemos construir uma democracia tendo em vista a superação dos conflitos de gênero, de raça e de classe social, o que só será possível pela defesa de direitos das minorias. Isso só será conquistado se as próprias minorias chegarem ao poder. Temos um foco que é o poder de governar. Queremos ocupar o governo. Teremos uma bancada feminista. PartidA é, sobretudo, uma ocupação, a qual pretende colocar o feminismo no governo. Mas, estamos ainda experimentando e construindo a ideia, e as práticas com as pessoas que vêm dar a \#partidA com a gente. Essa é a característica do nosso ativismo: democracia com as outras (e outros, e outres, e outrxs). O empoderamento da outra é o que a gente busca na intenção de manter a nossa horizontalidade, sem hierarquia, e com muito acolhimento.

\section{Você esperava toda a resposta virtual e presencial à PartidA, ou foi uma surpresa o sucesso inicial, desde 2015?}

MT: Sinceramente, espero muito e espero mais. Eu tenho muita esperança no que estamos fazendo. Confio nas mulheres feministas, confio na força das/os excluídas/os, confio totalmente na capacidade de luta das e dos que foram oprimidos e oprimidas. Não deixaremos de ser lúcidas e práticas porque somos utopistas e idealistas. Acredito que uma força política que precisa ser movida é justamente a nossa esperança, que tem sido aviltada e proibida pelo utilitarismo do sistema da opressão sedutora em que vivemos. 